beoordeling van het optreden en de invloed van de Vlaamse vloot, maar ook zouden recente studies over de kaapvaart en bemanningsproblemen hem nieuwe inzichten hebben verschaft en zijn thematische hoofdstukken hebben versterkt. In het bijzonderde officieren en zeelieden van marine en kaapvaart vormden een onmisbaar en uitzonderlijk belangrijk element in Spanjes zeemacht. De terechtgestelde onderbevelhebber van admiraal Homa ( 1640) wordt niet eens met name genoemd. Vanuit een Nederlands, en meer nog Vlaams, perspectief is het bepaald niet zonder belang de bewijzen van een sterke lokale zeevarende traditie naar voren te halen.

The Armada of Flanders is een interessante synthese, die echter zeker niet in alle opzichten het laatste woord biedt. Dikwijls meer verhalend dan analyserend, plaatst het de Vlaamse vloot ook te weinig in het grote kader van Spanjes wanhopig gevecht tegen de ineenstorting van zijn wereldrijk - of de politiek van Philips II de grootste schuld aan de overspannen expansie van dat rijk droeg, is natuurlijk weer een andere kwestie, die Stradling overigens best had mogen aansnijden. Deze vraag zou dan hebben kunnen voeren tot een beredeneerd eindoordeel over de Vlaamse vloot en diens betekenis: een conclusie, die nu helaas ontbreekt.

\title{
F. J. A. Broeze
}

N. Wickenden, C. J. Vossius and the humanist concept of history (Respublica literaria neerlandica V1I1; Assen: Van Gorcum, 1993, xxix + 251 blz., f59,90, ISBN 902322573 2).

In het proefschrift van C. Rademaker uit 1967 werd reeds gerefereerd aan deze studie van Vossius' denken over geschiedenis, die in 1963 als 'doctoral thesis' aan King's College in Cambridge tot stand kwam. Na dertig jaar is hij nu in boekvorm verschenen en kan iedereen van de bijgewerkte inhoud kennis nemen. Wickenden geeft eerst een overzicht van Vossius' leven, dat naar zijn opvatting vooral gedomineerd werd door diens behoefte aan status en eendracht. Opmerkelijk is dan ook voor wie de vele humanistenruzies kent hoe weinig hij felle polemieken heeft gevoerd en hoe hij erin slaagde in godsdienstige zaken met orthodoxen èn vrijzinnigen op vriendelijke voet te staan. De auteur richt zich vervolgens op Vossius' historische produktie. Volgens hem moeten deze boeken alle als reactie op bepaalde ontwikkelingen in de wereld om Vossius heen worden beschouwd en hebben zij ondanks de schijn van het tegendeel geen dorre antiquarische opzet. Hij laat zien hoe dit vooral opgaat voor zijn kerkgeschiedenis die te maken had met de godsdienstige twisten van het moment. Ook Vossius' theoretische werken als de Ars historica vertonen deze praktische kant. Vossius was inderdaad geen origineel denker, maar iemand die samenvatte, systematiseerde en met een onafhankelijk oordeel keek. Hierna bespreekt Wickenden de verhouding tussen religie en filosofie bij Vossius en bij dit vraagstuk kunnen we eveneens waarnemen hoe eclectisch hij te werk ging en hoe weinig leerstellig zijn geloof was. Vossius' definiëring van de geschiedenis was evenmin zuiver filosofisch, want hij liet oudere literaire opvattingen over geschiedschrijving erin meespelen. Eigenlijk dacht hij (in de visie van de auteur) te veel aan het schrijven van geschiedenis in plaats van aan het onderzoeksprobleem. Wickenden toont op heldere wijze aan hoe beperkt Vossius' benadering van de bronnen was, terwijl de bijbelse versie van het verleden onaantastbaar bleef. De traditie was ook beeldbepalend waar het Vossius' algemene kijk op de geschiedenis met een onveranderlijke menselijke natuur betrof. De auteur geeft verder een goede indruk hoe Vossius wat periodisering, politieke opvattingen, culturele en kerkgeschiedenis aangaat nauwelijks kennis had genomen van afwijkende visies op deze materie. Tenslotte wordt diens historische filosofie besproken waarbij het natuurlijk gaat om de plaats van de voorzienigheid in de geschiedenis 
waartegenover dan de menselijke vrijheid staat. Het is een erudiet en rijk boek dat getuigt van kennis van zaken.

Er kan echter een 'maar' bij dit alles worden geformuleerd. Wickenden is er namelijk van overtuigd dat Vossius moet worden geplaatst in de history of thought en kennelijk niet in die van de geschiedenis van de geschiedschrijving. Dit ondanks zijn kennis van de desbetreffende literatuur. Vossius wordt bijgevolg gezien als een filosoof die in zijn beschouwingen een sluitend systeem had moeten construeren. Het gevolg van deze benadering is dat hem eigenlijk onrecht wordt aangedaan omdat veel meer van deze humanistische, pragmatische geschiedbeschouwer en schrijver wordt gevergd dan hij met zijn achtergrond zou kunnen bieden. Daarom spreekt Wickenden - onbekommerd lijkt het over de scheiding van de beide genres - van 'forbidding antiquarianism' in verband met Vossius, daarom is zijn werk over het Pelagianisme 'anything but disinterested' alsof een historische auteur dat toen ooit was. Daarom wordt Croce's opvatting in zijn History as the story of liberty over de taak van de geschiedenis te reageren op de omstandigheden van het moment, als autoriteit opgevoerd (30). Daarom hebben we al gezien dat Vossius wordt berispt zijn eigen filosofische categorieën niet aan te houden. $\mathrm{Nu}$ is het inderdaad zo dat Vossius het woord philosophia gebruikte, maar hij zette zich daarmee in de humanistisch-rhetorische visie op de geschiedenis aftegen kroniekachtige opsommerij. De prudence die Wickenden bij zijn onderwerp signaleert is dan ook niet slechts wijsheid in de geschiedenis, maar staatsmanswijsheid in een politiek georiënteerde opvatting van geschiedbeoefening. We mogen Vossius dus niet, zoals de auteur doet, verwijten dat hij meer aandacht gaf aan het schrijven van een historie dan aan het historisch onderzoek zelf (85). Zijn roepen om waarheid in de geschiedenis had dan ook een andere betekenis dan tegenwoordig en het is derhalve een waarheid als een koe en geen 'measure of truth' dat "rhetorical' historiography tended to manipulate, rather than to liberate, the minds of its readers' (86). Ook de beschouwing, onder aanhaling van Collingwoods werk (120), dat Vossius erg zelden een beroep deed op historische inleving bij zijn geschiedbeschouwing doet toch wel buitengewoon anachronistisch aan om maar te zwijgen van de keer dat de auteur hem kapittelt wegens het feit dat hij zo weinig interpretatie in zijn kerkgeschiedenis verwerkt (171). Ook bij het gebruik van de termen 'historische ontwikkeling', ja zelfs 'vooruitgang' met betrekking tot zeventiende-eeuwse geschiedschrijving zou menige kanttekening kunnen worden gezet, al moet toegegeven worden dat de auteur nog terloops opmerkt 'it seems, however, that Vossius was less impressed by progress and decline than by the uniformity of history ...' (177).

De slotsom kan dus geen andere zijn dan dat dit boek ons enerzijds een veelzijdig beeld geeft van Vossius' intellectuele krachten op het gebied van de geschiedenis, maar anderzijds de lezer een perspectief biedt dat niet altijd bij de achtergrond past van waaruit de 'hooggeleerde Vos' juist die overwegingen neerschreef.

E. O. G. Haitsma Mulier

J. Ockeley, De gasthuiszusters en hun ziekenzorg in het aartsbisdom Mechelen in de 17de en de 18de eeuw. Bijdrage tot de studie van de actieve vrouwelijke kloostercongregaties (2 dln., Dissertatie, Extranummer Archief- en Bibliotheekwezen in België XLIV; Brussel: Archief- en Bibliotheekwezen in België, 1992,954 blz.).

Deze omvangrijke studie, herwerkte versie van een doctoraatsproefschrift en bekroond met de mgr. C. de Clercqprijs 1992, wil de aandacht vestigen op een 'vergeten' groep van kloosterlin- 